\title{
Evidence for highly refractory, heat producing element-depleted lower continental crust in eastern Australia
}

\author{
ROBERT EMO AND BALZ S KAMBER
}

Queensland University of Technology

Presenting Author: robertbernard.emo@hdr.qut.edu.au

The formation and evolution of the lower continental crust remain enigmatic, and lower crustal compositional estimates show significant variability, particularly for the highly incompatible elements. The lower crustal composition is reconstructed from geochemical data of xenoliths. A challenge is that many xenoliths are too small to be analysed by conventional bulk rock analysis, and xenoliths are entrained by highly enriched volcanic rocks, posing a contamination risk. Here we investigated the chemistry of lower crustal xenoliths from central Queensland, an understudied part of the xenolith-bearing eastern Australian basalt provinces. The dominant xenolith lithologies are simple two-pyroxene, plagioclase granulites with very few accessory phases. We used a microanalytical approach to reconstruct the xenoliths' primary compositions and explore the degree to which the xenoliths were affected by their carrier basalts. The chemistry was determined by combining the modal mineralogy from automated full-thin section SEM-EDS phase mapping with mineral chemistry from electron microprobe and LA-ICP-MS analysis. The SEM-EDS mapping revealed that $\mathrm{K}$ is enriched in grain boundary networks and fractures in granulite and co-occurring mantle xenoliths, and high spatial resolution LA-ICP-MS 2-D traverses show that the same networks are also significantly enriched in many highly incompatible elements. These networks likely formed during xenolith dislodgment and subsequent entrainment within the host basalt. The uncontaminated mineral compositions are significantly depleted in the incompatible elements, including the heat producing elements, and the overall reconstructed compositions reveal highly refractory lower crust. Thermodynamic modelling comparisons indicate the granulites are restites of anatectic calcalkaline basalts or diorites that experienced significant (40-60\%) melt loss at $\mathrm{T}>1,000{ }^{\circ} \mathrm{C}$. Corresponding Permian-Triassic upper crustal granitoids of the northern New England orogen in eastern Australia have complementary geochemical signatures to the granulites, and they likely represent the escaped melt. We interpret the granulite xenoliths to represent the residual material after protracted melting caused by lithospheric thinning and underplating of basaltic magmas. 